\title{
Application of Chow Test to Estimate the Effect of Mutual Recognition Agreements
}

\author{
Iosif Z. Aronov \\ Department of Trade and Trade regulation \\ MGIMO (Moscow State Institute of International Relations) University, Moscow, Russia \\ International Trade and Integration (ITI) Research Center, Moscow, Russia \\ Corresponding author: izaronov@itandi.ru \\ Anna M. Rybakova \\ Department of Trade and Trade Regulation \\ MGIMO (Moscow State Institute of International Relations) University, Moscow, Russia \\ Department of Trade Barriers Analysis, International Trade and Integration (ITI) Research Center \\ Moscow, Russia \\ E-mail: amrybakova@itandi.ru \\ Vladimir Yu. Salamatov \\ Department of Trade and Trade Regulation \\ MGIMO (Moscow State Institute of International Relations) University, Moscow, Russia \\ International Trade and Integration (ITI) Research Center, Moscow, Russia \\ E-mail: info@itandi.ru \\ Anna V. Tangaeva \\ Trade Regime Analysis Division \\ International Trade and Integration (ITI) Research Center, Moscow, Russia \\ E-mail: avtangaeva@itandi.ru \\ Nataliia M. Galkina \\ Department of Trade Barriers Analysis \\ International Trade and Integration (ITI) Research Center, Moscow, Russia \\ E-mail: nmgalkina@itandi.ru
}

(Received January 4, 2019; Accepted February 10, 2019)

\begin{abstract}
This article presents the research results on Mutual Recognition Agreement effect on the volume of exports - imports of the countries (parties) in the context of the EU - Israel Mutual Recognition Agreement. The authors used the Chow test to obtain the results. The article shows that there is no good reason to believe that Mutual Recognition Agreements boost the volume of mutual trade, at least, of pharmaceutical products. In other words, Mutual Recognition Agreements do not contribute to the growth in the number of exporters. It is concluded that the primary effect of such agreements is to facilitate conformity assessment procedures.
\end{abstract}

Keywords- Export, Technical Regulation, Mutual Recognition Agreement, Barriers In Trade, Chow Test.

\section{Introduction}

As in any other area, there are stable stereotypes in the area of technical regulation (Aronov et al., 2019). They include, inter alia, the mythologization of intergovernmental Mutual Recognition 
International Journal of Mathematical, Engineering and Management Sciences

Vol. 4, No. 3, 591-600, 2019

https://dx.doi.org/10.33889/IJMEMS.2019.4.3-047

Agreements on results of conformity assessment $\left(\mathrm{MRAs}^{1}\right)$ as the most effective tool for reduction of technical barriers to trade.

It is commonly known that one of the most significant barrier to trade is associated with the application of conformity assessment procedures and forms to comply with mandatory requirements to goods. Generally, Mutual Recognition Agreements on results of conformity assessment between states are based on Article 6.1 of the WTO Agreement on Technical Barriers to Trade (TBT Agreement), according to which the WTO Members "shall ensure, whenever possible, that results of conformity assessment procedures in other Members are accepted, even when those procedures differ from their own, provided they are satisfied that those procedures offer an assurance of conformity with applicable technical regulations or standards equivalent to their own procedures".

MRAs are considered as a way to decrease time and financial implications, which result from application of conformity assessment procedures and forms to goods in the country of origin and destination country. Bilateral intergovernmental MRAs are legally binding agreements between two countries, which enable to conduct conformity assessment (testing, inspection, certification) of goods intended to export to the market of another party in the exporting country (country of origin). Regulatory authorities of both parties of the MRA must accept test reports and certificates, issued by those conformity assessment bodies, which both parties consider as competent to assess compliance with mandatory (regulatory) requirements of the other party. As a general rule, MRAs ${ }^{2}$ do not involve harmonization of standards or technical regulations of the parties, but require a standing credibility of the parties in the systems and procedures of accreditation, as well as to the conformity assessment bodies. Obviously, strengthening of trust between the two parties becomes more complex when technical requirements and generic regulatory approach are significantly different.

To date, the European Union (EU) has gained the largest experience in application of MRAs as given in a Table 1.

As noted, a considerable experience has been gained in the area of the MRAs, however, the effect estimation of the agreements on trade between the parties is rather ambiguous as presented in a Table 2.

According to the European Commission (EC) (Commission Staff Working Paper, 2004), it is almost impossible to determine economic results of the agreements and their impact on trade in quantitative terms, since none of the parties to the agreements keeps records of "recognized" certificates or test reports. Many countries believe that the effect of MRAs on trade has been considerably exaggerated.

\footnotetext{
${ }^{1}$ Mutual Recognition Agreement — author's note.

${ }^{2}$ It is referred to classic MRA. - author's note.
} 
International Journal of Mathematical, Engineering and Management Sciences

Vol. 4, No. 3, 591-600, 2019

https://dx.doi.org/10.33889/IJMEMS.2019.4.3-047

Table 1. Mutual Recognition Agreements between the EU and third countries

\begin{tabular}{|c|c|c|}
\hline No. & Agreement & Sectoral Coverage \\
\hline 1 & $\begin{array}{l}\text { AGREEMENT on mutual recognition in relation to conformity } \\
\text { assessment, certificates and markings between the European } \\
\text { Community and Australia, } 1998 \text { (amended in 2012) }\end{array}$ & $\begin{array}{l}\text { Automotive products and machinery, low voltage } \\
\text { equipment, medical devices, pressure equipment, GMP } \\
\text { (pharmaceutical products) }\end{array}$ \\
\hline 2 & $\begin{array}{l}\text { AGREEMENT on mutual recognition in relation to conformity } \\
\text { assessment between the European Community and New } \\
\text { Zealand, } 1998 \text { (amended in 2012) }\end{array}$ & $\begin{array}{l}\text { Automotive products and machinery, low voltage } \\
\text { equipment, medical devices, pressure equipment, GMP } \\
\text { (pharmaceutical products) }\end{array}$ \\
\hline 3 & $\begin{array}{l}\text { AGREEMENT on mutual recognition between the European } \\
\text { Community and the United States of America, } 1999\end{array}$ & $\begin{array}{l}\text { Telecommunication equipment, electromagnetic } \\
\text { compatibility (EVC), Electrical safety, recreational craft, } \\
\text { pharmaceutical Good Manufacturing Practices (GMP), } \\
\text { medical devices }\end{array}$ \\
\hline 4 & $\begin{array}{l}\text { AGREEMENT on mutual recognition of OECD } \\
\text { principles of good laboratory practice (GLP) and } \\
\text { compliance monitoring programmes between the } \\
\text { European Community and the State of Israel, } 1999\end{array}$ & $\begin{array}{l}\text { GLP (testing of cosmetics, industrial chemicals, } \\
\text { pharmaceuticals, food additives, animal feed additives, } \\
\text { pesticides) }\end{array}$ \\
\hline 5 & $\begin{array}{l}\text { AGREEMENT on mutual recognition between the } \\
\text { European Community and Japan, } 2001\end{array}$ & $\begin{array}{l}\text { Telecommunications terminal equipment, low voltage } \\
\text { equipment, Good Laboratory Practices, GLP (chemicals } \\
\text { testing), GMP (pharmaceutical products) }\end{array}$ \\
\hline 6 & $\begin{array}{l}\text { AGREEMENT between the European Community and the } \\
\text { Swiss Confederation on mutual recognition in relation to } \\
\text { conformity assessment, } 2002\end{array}$ & $\begin{array}{l}\text { Machinery, personal protective equipment, toys, medical } \\
\text { devices, gas appliances and boilers (hot water boilers), } \\
\text { pressure vessels, radio equipment and telecommunication } \\
\text { terminal equipment, equipment and protective systems } \\
\text { intended for use in potentially explosive atmospheres, } \\
\text { electrical equipment, construction plant and equipment, } \\
\text { measuring instruments and pre-packages, motor vehicles, } \\
\text { agricultural and forestry tractors, GLP, medicinal products, } \\
\text { GMP, inspection batch and certification, construction } \\
\text { products, lifts, biocidal products, cableways, explosives for } \\
\text { civil use }\end{array}$ \\
\hline 7 & $\begin{array}{l}\text { Protocol to the Euro-Mediterranean Agreement establishing an } \\
\text { association between the European Communities and their } \\
\text { Member States, of the one part, and the State of Israel, of the } \\
\text { other part, on Conformity Assessment and Acceptance of } \\
\text { Industrial Products (CAA), } 2013\end{array}$ & GMP (pharmaceutical products) \\
\hline 8 & $\begin{array}{l}\text { Protocol on the mutual acceptance of the results of conformity } \\
\text { assessment is part of the Comprehensive Economic and Trade } \\
\text { Agreement (CETA) between Canada, of the one part, and the } \\
\text { European Union and its Member States, of the other part, } 2017\end{array}$ & $\begin{array}{l}\text { Electrical and electronic equipment, including electrical } \\
\text { installations and appliances, and related components; radio } \\
\text { and telecommunications terminal equipment, } \\
\text { electromagnetic compatibility (EMC), toys, construction } \\
\text { products, machinery, including parts, components, } \\
\text { including safety components, interchangeable equipment, } \\
\text { and assemblies of machines; measuring instruments, hot- } \\
\text { water boilers, including related appliances; equipment, } \\
\text { machines, apparatus, devices, control components, } \\
\text { protection systems, safety devices, controlling devices and } \\
\text { regulating devices, and related instrumentation and } \\
\text { prevention and detection systems for use in potentially } \\
\text { explosive atmospheres (ATEX equipment); equipment for } \\
\text { use outdoors as it relates to noise emission in the } \\
\text { environment; recreational craft, including their } \\
\text { components }\end{array}$ \\
\hline
\end{tabular}


International Journal of Mathematical, Engineering and Management Sciences

Vol. 4, No. 3, 591-600, 2019

https://dx.doi.org/10.33889/IJMEMS.2019.4.3-047

Table 2. Research results of Mutual Recognition Agreements effect on trade (Correia de Brito et al., 2016)

\begin{tabular}{|c|c|c|}
\hline Type of research & Results & Commentaries \\
\hline $\begin{array}{lr}\text { Qualitative } & \text { studies } \\
\text { (interviews, } & \text { polling, } \\
\text { questionnaire) } & \end{array}$ & $\begin{array}{l}\text { Nine studies. } \\
\text { Six out of nine - positive effect; three out of } \\
\text { nine - minor effect or no effect }\end{array}$ & $\begin{array}{l}\text { The results of the three studies, which showed } \\
\text { minor effect or no effect, may be attributed to: } \\
\text { a) Lack of implementation; } \\
\text { b) Rules of origin; } \\
\text { c) Poor infrastructure (in developing } \\
\text { countries) }\end{array}$ \\
\hline Econometric studies & $\begin{array}{l}\text { Three studies. } \\
\text { Two out of three - positive effect; one out of } \\
\text { three - no effect }\end{array}$ & $\begin{array}{l}\text { The result of one study, which showed no effect, } \\
\text { may be attributed to: } \\
\text { a) Small volume of mutual trade (case of } \\
\text { the EU-Australia Mutual Recognition Agreement. } \\
\text { The study was conducted 2-3 years after entry of } \\
\text { agreement into force) }\end{array}$ \\
\hline
\end{tabular}

Both qualitative and econometric studies can demonstrate no effect or even negative effect of Mutual Recognition Agreements on exports-imports of the parties to the agreement. The authors assume that the reasons for such effects are lack of implementation of the agreements, poor infrastructure of the conformity assessment bodies (for qualitative studies), insufficient agreement duration to achieve considerable effect and a small volume of mutual trade (Correia de Brito et al., 2016).

\section{Objectives of the Research}

This article presents the research results on the effect of Mutual Recognition Agreements on the volume of exports-imports of the countries (parties) in the context of the EU-Israel Mutual Recognition Agreement (Protocol to the Euro-Mediterranean Agreement establishing an association between the European Communities and their Member States, of the one part, and the State of Israel, of the other part, on Conformity Assessment and Acceptance of Industrial Products (CAA), 2013). For the research this agreement was not chosen by accident. This is one of the latest agreements on mutual recognition and it concerns only the recognition of $\mathrm{GMP}^{3}$ rules and conformity assessment of pharmaceutical products manufacturers to these rules. This agreement relates to a certain industry (pharmaceutical products) and is based on high equivalence requirements between the parties to the agreement - prior to its signing, Israel adopted the relevant legislation amendments in the field of pharmaceuticals, which ensured the application of European GMP requirements. Therefore, it can be considered that the principal technical barrier for pharmaceutical products in this situation is precisely the difference in the registration rules for such products in Israel and the EU Member States, and not in the GMP manufacturing requirements.

Over the past decades, mutual trade between the EU and Israel has been characterized by positive dynamics, which has been accompanied by significant changes in trade patterns. Before 2009, the balance of mutual trade in pharmaceutical products was positive for the EU and negative for Israel. However, from 2010, Israel's value of exports has significantly exceeded trade flows from the EU.

According to the EU statistics, exports of pharmaceutical products from the EU to Israel under product classification 30 (HS code) amounted to USD 371.8 Million in 2001. In subsequent years,

\footnotetext{
${ }^{3}$ Good Manufacturing Practice - a system for ensuring that products are consistently produced and controlled according to quality standards.
} 
International Journal of Mathematical, Engineering and Management Sciences

Vol. 4, No. 3, 591-600, 2019

https://dx.doi.org/10.33889/IJMEMS.2019.4.3-047

exports from the EU countries to Israel were consistently increasing, and by 2017 it amounted to USD 1,363 Million. The major exports items throughout the period are "other prepackaged pharmaceutical products" and "immunological products".

\section{Regression Analysis With The Chow Test}

Regression analysis is a means of exploring the presence/absence of connection between two factors. The effectiveness of such analysis has been demonstrated in a number of studies (Anand and Bansal, 2016; Bose and Pain, 2018; Bhullar and Gill, 2019).

Issue on presence/absence of the agreement effect between the countries is directly related to the statistical task to examine data structural changes of exports after the agreement was signed in 2013. For this task the Chow test ${ }^{4}$ was applied (Chow, 1960).

Exports volume of pharmaceutical products from the EU to Israel (USD Million) by year is the following: ${ }^{5}$

$\begin{array}{llr}2001-371,8 & 2007-616,4 & 2013-1001,6 \\ 2002-386,6 & 2008-769,0 \ldots \ldots \ldots .2014-1247,5 \\ 2003-426,4 \ldots \ldots & 2009-839,7 \ldots \ldots \ldots \ldots . .2015-1163,7 \\ 2004-462,6 & 2010-931,5 & 2016-1245,4 \\ 2005-508,7 & 2011-952,0 \ldots \ldots \ldots \ldots .2017-1363,2 \\ 2006-514,6 \ldots \ldots \ldots & 2012-951,4 & \end{array}$

The Chow test provides an answer which tendency model describes time series in the best way: general linear model based on all the values of the time series from 2001 to 2017, or piecewiselinear model, which consists of two linear models (before 2013 - before the agreement was signed, and from 2013 to 2017 - after the agreement was signed).

As illustrated above, exports values from the EU to Israel for the period from 2001 to 2017 (USD Million) and equation of linear regression with coefficient of determination $\mathrm{R}^{2}=0,9706$. Regression models of linear and piecewise linear regressions for the given data are presented in Table 3.

Table 3. Regression models describing exports dynamics of pharmaceutical products from the EU to Israel

\begin{tabular}{|c|c|c|c|c|}
\hline Type of Model & Years & Formula for the calculation & R-squared $\left(\mathbf{R}^{2}\right)$ & $\begin{array}{c}\text { Error Sum of Squares } \\
(\text { ESS })\end{array}$ \\
\hline General model & $2001-2017$ & $\hat{y}=64725 x-(1 E+08)$ & 0,9706 & 51832772575,5 \\
\hline $\begin{array}{c}\text { Piecewise- } \\
\text { linear model } \\
\text { (p.1) }\end{array}$ & $2001-2012$ & $\hat{y}=62131 x-(1 E+08)$ & 0,9478 & 30429307126,6 \\
\hline $\begin{array}{c}\text { Piecewise- } \\
\text { linear model } \\
(\mathrm{p} .2)\end{array}$ & $2013-2017$ & $\hat{y}=72106 x-(1 E+08)$ & 0,7267 & 19550404113,1 \\
\hline
\end{tabular}

\footnotetext{
${ }^{4}$ Chow test - a test of whether the true coefficients in two linear regressions on different data sets are equal. $-a d$. note.

${ }^{5}$ Source: International Trade Center.
} 
International Journal of Mathematical, Engineering and Management Sciences

Vol. 4, No. 3, 591-600, 2019

https://dx.doi.org/10.33889/IJMEMS.2019.4.3-047

The null hypothesis $H_{0}$ in the Chow test assumes the absence of data structural changes against alternative hypothesis $H_{1}$ on the existence of such changes. In terms of the research objectives, the Chow test enables to determine whether exports volume from the EU to Israel has changed since 2013 (since the conclusion of the agreement) compared with the period from 2001 to 2012.

Statistics of the Chow test is the following:

$F=\frac{\left(E S S-E S S_{1}-E S S_{2}\right) / k}{\left(E S S_{1}+E S S_{2}\right) /(n-2 k)} \sim F(k, n-2 k)$

where $E S S, E S S_{1}, E S S_{2}$ - the residual sums of squares for the general and piecewise linear model (p.1 and p. 2, see Table 3), $n$ - data volume, $k=2$ - amount of coefficients of the regression model, $F(k, n-2 k)-$ Fisher statistic, with $k$ and $n-2 k$ the degrees of freedom and a predetermined significance level $\alpha$. If $F_{\text {estimated }}>F_{\text {critical }}$, then the hypothesis on structural stability is rejected, and the impact of structural changes on dynamics of the test characteristic is recognized as significant. In this case, a piecewise linear model is chosen, i.e. it is recognized that the agreement had a significant impact on exports volume of pharmaceutical products from the EU to Israel.

If $F_{\text {estimated }}<F_{\text {critical }}$, then there is no reason to reject the hypothesis on structural stability of the trend, i.e. it should be assumed that the agreement did not impact imports volume of pharmaceutical products from the EU to Israel.

So, suppose we set significance level $\alpha$ at $5 \%$. By using data of the Table 3, we deduce $F_{\text {estimated }}$ $=0,278072, F_{\text {critical }}=F(15 ; 2)=3,6823203$. As far as $F_{\text {estimated }}<F_{\text {critical }}$, that is, we conclude data structural stability of the time series in favor of accepting hypothesis $H_{0}$.

Therefore, the agreement between the EU and Israel, at the average, had no change effect on exports volume of pharmaceutical products from the EU countries to Israel.

The next step is to analyze exports volume of pharmaceutical products from Israel to the EU. Exports volume of pharmaceutical products from the EU to Israel (USD Million) by year:

$\begin{array}{llr}2001-89,1 & 2007-571,8 & 2013-2673,4 \\ 2002-115,6 & 2008-643,9 \ldots \ldots \ldots .2014-3134,6 \\ 2003-217,1 \ldots \ldots & 2009-629,4 \ldots \ldots \ldots \ldots .2015-3208,9 \\ 2004-294,2 & 2010-1464,4 & 2016-3166,3 \\ 2005-433,9 & 2011-2479,4 \ldots \ldots \ldots .2017-3959,6 \\ 2006-374,9 \ldots \ldots \ldots & 2012-2609,8 & \end{array}$

According to Israel's statistics, exports of pharmaceutical products to the EU, represented by product classification 30 (HS Code), amounted USD 89,1 Million in 2001. Over the next eight years, exports of pharmaceutical products to the EU has gradually increased. The greatest increase was recorded in 2010, when in the course of the year Israel increased exports to the EU market by $133 \%$, i.e. from USD 629 to 1,464 Million. 
International Journal of Mathematical, Engineering and Management Sciences

Vol. 4, No. 3, 591-600, 2019

https://dx.doi.org/10.33889/IJMEMS.2019.4.3-047

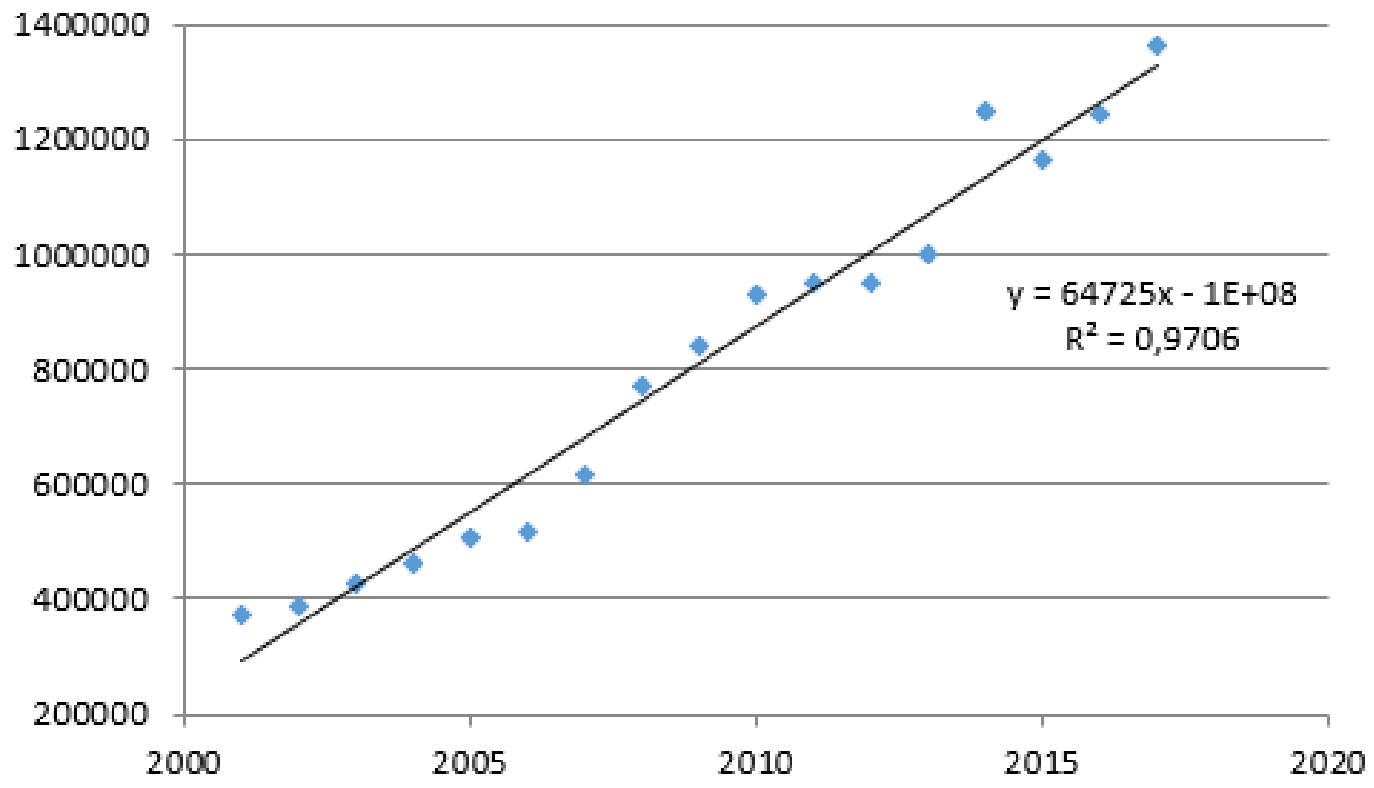

Figure 1. Exports volume of pharmaceutical products from Israel to the EU, 2001-2017 (USD Thousand)

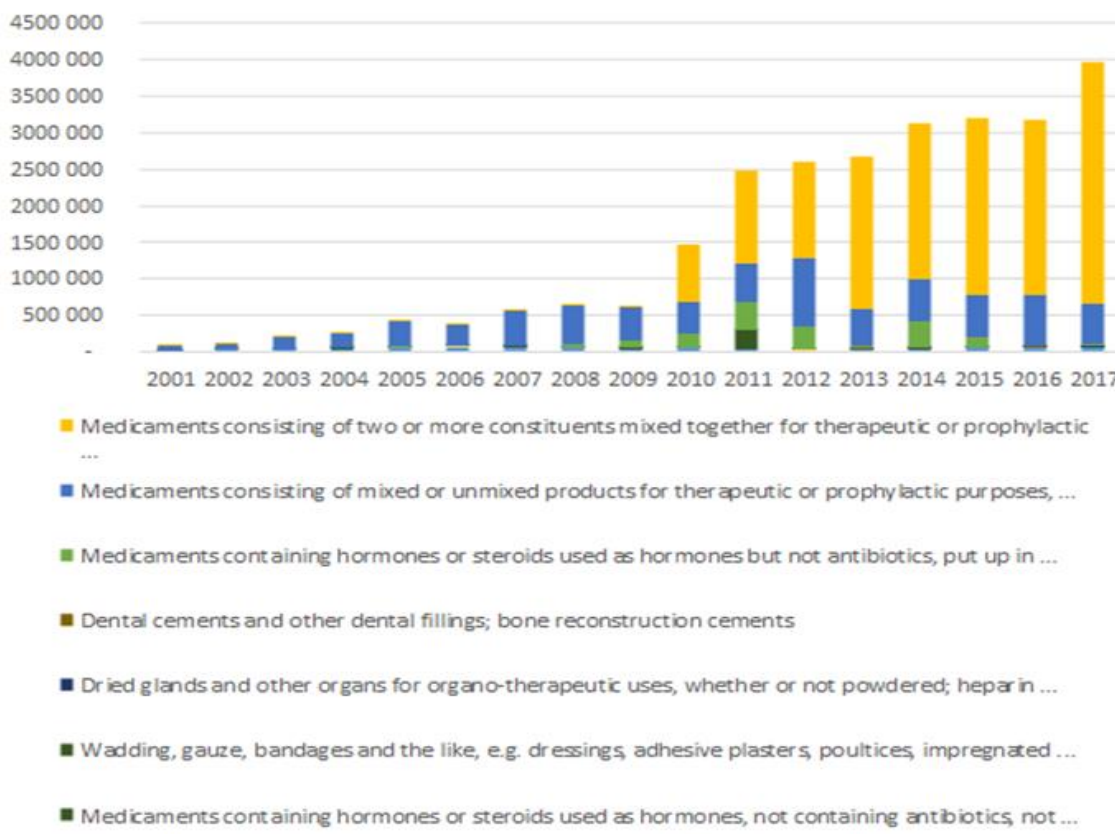

Figure 2. Exports of pharmaceutical products from Israel to the EU (by product type) 
International Journal of Mathematical, Engineering and Management Sciences

Vol. 4, No. 3, 591-600, 2019

https://dx.doi.org/10.33889/IJMEMS.2019.4.3-047

A primary statistical and qualitative data analysis showed that from 2009 there is a special impact cause on exports volume of pharmaceutical products from Israel (see Figure 1).

The aforementioned exports increase was due to the start of large-scale imports of products, classified as "Medicaments consisting of two or more constituents mixed together..." (HS Code 3003 90) to the EU, namely to the UK. In 2010, exports of other unpackaged pharmaceutical products increased from USD 23 to 775 Million. That was the largest Israel's exports of pharmaceutical products to the EU (see Figure 2). At the same time, there was insignificant exports increase to other countries (exports increase of the products under HS Code 300390 to all countries (except the EU) amounted to USD 45 Million.

Therefore, to assess the impact of the EU- Israel agreement, exports volume from 2009 to 2017 was analyzed with the Chow test (see Figure 3).

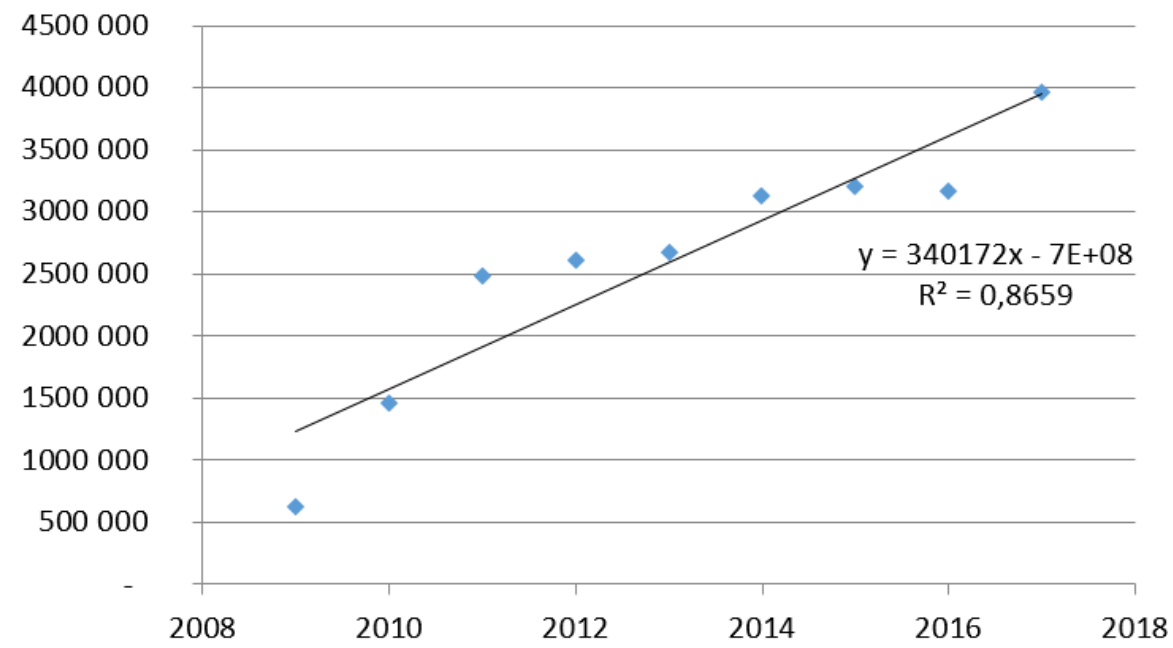

Figure 3. Exports volume of pharmaceutical products from Israel to the EU, 2009-2017 (USD Thousand)

The equation of linear regression, constructed according to the data for the period from 2009 to 2017 has a coefficient of determination $R^{2}=0,8659$, which shows, that, at the average, $86.59 \%$ of data variation is determined by the described model. The linear and piecewise linear regression models for the data are presented in the Table 4.

Table 4. Regression models describing exports dynamics of pharmaceutical products from Israel to the EU

\begin{tabular}{|c|c|c|c|c|}
\hline Type of Model & Years & Formula for the calculation & R-squared $\left(\mathbf{R}^{2}\right)$ & $\begin{array}{c}\text { Error Sum of Squares } \\
(\text { ESS })\end{array}$ \\
\hline General model & $2009-2017$ & $\hat{y}=340172 x-(7 E+08)$ & 0,8659 & 1075022956325,2 \\
\hline $\begin{array}{c}\text { Piecewise- } \\
\text { linear model } \\
\text { (p.1) }\end{array}$ & $2009-2012$ & $\hat{y}=695619 x-(1,4 E+09)$ & 0,9305 & 180780858191,5 \\
\hline $\begin{array}{c}\text { Piecewise- } \\
\text { linear model } \\
\text { (p.2) }\end{array}$ & $2013-2017$ & $\hat{y}=260395 x-(5,2 E+08)$ & 0,7925 & 19550404113,1 \\
\hline
\end{tabular}


International Journal of Mathematical, Engineering and Management Sciences

Vol. 4, No. 3, 591-600, 2019

https://dx.doi.org/10.33889/IJMEMS.2019.4.3-047

Next step is to apply the Chow test. Under similar hypotheses $H_{0}$ and $H_{1}$, suppose we set significance level $\alpha$ at $5 \%$. By using data of the Table 4 , we deduce $F_{\text {estimated }}=6,999864, F_{\text {critical }}$ $=F(7 ; 2)=4,737414$. Whereby, $F_{\text {estimated }}>F_{\text {critical }}$. That is, hypothesis $H_{1}$ (significant structural changes effect on indicator dynamics) is accepted. In other words, the agreement has a significant effect on exports volume from Israel to the EU.

Further step is to determine the direction of the observed effect. The analysis (p.1 and p.2, see Table 4) shows that the angle of slope coefficient of the regression line (variable held constant $x$ ) for the second part of the piecewise linear model is less than a similar coefficient for the first part of the piecewise linear model. This indicates a decrease of exports growth trend after 2013. Therefore, there is no reason to believe that the agreement in question had a positive effect on exports volume of pharmaceutical products from Israel to the EU.

\section{Conclusion}

The subtotal is the following. The Chow test application for the time series, characterizing the dynamics of exports operations between the EU and Israel from 2001 to 2017 with respect to pharmaceutical products, testifies that the EU - Israel agreement, at the average, did not have a positive effect on exports - imports volume of pharmaceutical products between the parties. In other words, the volume growth of shipments between Israel and the EU was caused by the general growth trend in mutual trade, and not by a special cause, related to the conclusion of a Mutual Recognition Agreement.

This particular example demonstrates the fact that the "benefits" of conclusion of Mutual Recognition Agreements on results of conformity assessment are exaggerated, since there is even evidence of a negative effect. This does not mean the rejection of possibility to conclude such agreements, but the main "benefits" of such agreements may be considered in a different context, such as, facilitation of conformity assessment procedures for specific exporters, and not the growth in the number of new exporters.

\section{Conflict of interests}

The authors confirm that there is no conflict of interest to declare for this publication.

\section{Acknowledgement}

The authors would like to express their thanks to the reviewers for their valuable suggestions towards the improvement of the paper.

\section{References}

Anand, A., \& Bansal, G. (2016). Predicting customer's satisfaction (dissatisfaction) using logistic regression. International Journal of Mathematical, Engineering and Management Sciences, 1(2), 77-88.

Aronov, I., Rybakova, A., Salamatov, V., \& Maksimova, O. (2019). Technical regulation myths in the area of international trade. Standards and Quality (Vol. 1). Moscow, Russia. doi:https://riastk.ru/stq/adetail.php?ID=174515/. 
International Journal of Mathematical, Engineering and Management Sciences

Vol. 4, No. 3, 591-600, 2019

https://dx.doi.org/10.33889/IJMEMS.2019.4.3-047

Bhullar, A., \& Gill, P.S. (2019). Future of mobile commerce: an exploratory study on factors affecting mobile users' behaviour intention. International Journal of Mathematical, Engineering and Management Sciences, 4(1), 245-258.

Bose, G., \& Pain, P. (2018). Metaheuristic approach of multi-objective optimization during EDM process. International Journal of Mathematical, Engineering and Management Sciences, 3(3), 301-314.

Chow, G.C. (1960). Tests of equality between sets of coefficients in two linear regressions. Econometrica, 28(3), 591. doi:10.2307/1910133.

Commission Staff Working Paper Priorities for Bilateral .. (2004). Retrieved from http://ec.europa.eu/DocsRoom/documents/6802/attachments/1/translations/en/renditions/native

Correia de Brito, A., Kauffmann, C., \& Pelkmans, J. (2016). The contribution of mutual recognition to international regulatory co-operation. OECD Regulatory Policy Working Papers , No. 2, OECD Publishing, Paris. http://dx.doi.org/10.1787/5jm56fqsfxmx-en 